\title{
ヒト胎児前庭神経核の形態計測学的検討方法について
} 藤井玉ゆ2 ${ }^{1)}$ ・後藤 昇 ${ }^{1)}$ - 木田 亮紀 ${ }^{2)}$ - 菊池 恭三 ${ }^{2)}$

\section{Morphometric Evaluation of the Human Fetal Vestibular Nuclei}

\author{
Mayumi Fujiii ${ }^{1)}$, Noboru Goto ${ }^{1)}$, Akinori Kida ${ }^{2)}$, Kyouzou Kikuchi ${ }^{2)}$ \\ 1) Department of Anatomy, Showa University School of Medicine \\ 2) Department of Otolaryngology, Nihon University School of Medicine
}

Morphometric observation and evaluation consisting of celloidine serial sections, a microscope with a drawing tube, an image analyser and a computer are necessary for the precise understanding of the morphological development of the human nervous system with great objectivity. We introduced this method and particular anatomic parameters such as the circularity ratio (CR) and neuropil index (NI) with the preliminary data of the vestibular nuclei at 40 weeks of gestation (WG). For the analysis of the maturity of neurons, $\mathrm{CR}$ of neuronal somata, $4 \pi \mathrm{A} / \mathrm{L}^{2}\left(\mathrm{~A}=\right.$ area in $\mu \mathrm{m}^{2} ; \mathrm{L}=$ perimeter in $\mu \mathrm{m}$ ), was calculated. The CR of a regular circle is 1.0 . We evaluated the maturation of the neuropil defined as the tissue around each neuron including the axons, dendrites, myelin sheaths, glial cell bodies and their processes, vessels and connective tissue. The NI was calculated as follows: $\mathrm{NI}=$ [(total columnar area in $\mathrm{mm}$ )- - (total neuronal area in $\mathrm{mm})] \times 10^{3}$ /neuronal number; We measured sections to obtain several morphometric parameters: the volume of the nuclear column, and number, packing density and cell body area of neurons, and calculated CR and NI, demonstrating the value at 40 WG. We are currently preparing to examine the development of the human lateral vestibular nucleus in 14 fetuses (6-40 WG), an infant (2 months old) and an adult (63 years old).

Key words: lateral vestibular nucleus, morphometry, development, human fetus, serial section

\section{はじめに}

日本平衡神経科学会第52回学術講演会のンンポ ジウム“平衡機能の発達とその障害”に打いて, 共著者が “前庭神経の発達”を講演した。そのな かで, ヒトの前庭神経系の形態学的発達について 紹介し，発達を正しく評価するためには，組織学 的な定性的検討の及ならず, 形態計測学的検討が 必要であることをのべた1)。今回私達は前庭神経

1) 昭和大学医学部第二解剖学教室

2) 日本大学医学部耳鼻咽喉科学教室
核群のひとつ外側核を選び，形態計測の方法と発 達の評価法について述べ, 40胎週齿の計測值を示 寸。

\section{材料と方法}

ヒト胎児の脳幹を，まず10\%フォルマリンで一 次固定を行った後にクロム酸二次固定を行い，水 洗, 脱水後, 七ロイジン包埋, 連続切片 $(30 \mu \mathrm{m}$ 厚）を作成した2)。連続切片は連続番号を切片每 に付し染色は10枚毎の切片を抜き出して, 当研究 のためには, Klüver-Barrera 染色（K-B 染色） を行った。神経核とは神経細胞体の集まりであ 
り, 膜で被われているわけではないので, 切片標 本を 1 枚のみ観察して神経核の境界がわかるもの ではない。そこで, 観察は実体顕微鏡を用い, 切 片標本を重ねて前庭神経外側核を核柱として観察 しながら標本上の外側核の境界を確認した。計測 にはdrawing tubeつき顕微鏡と画像解析装置を 組み合わせたものを用い, 核柱断面積は20倍で, 神経細胞体は268倍で, 光ファイバー付きカーソ ルでそれぞれの周囲をなぞって計測した。1 個の 神経細胞は 1 枚の切片に含まれることと, 何枚か の切片に分割されることがあるので, 計測の基準 をはっきりさせておかなければならない。そこで, 核小体（直径 $1 \mu \mathrm{m}$ 位）を目標として核小体のあ る神経細胞のみの計測を行った。計測処理と統計 解析には, 当教室の開発による形態計測システム ソフトと市販の統合型表計算ソフトLOTUS 123 を使用した。

統計解析のための指標として, 真円率 (CR) と neuropil index (NI) を用いた。真円率の計算 は $\mathrm{CR}=4 \pi \mathrm{A} / \mathrm{L}^{2}$ で求めることができる。 $\mathrm{A}$ は面積 値, L は周長である。neuropil index は NI= neuropil の面積 $\left(\mathrm{mm}^{2}\right) \times 10^{3 /}$ 神経細胞数で計算 される。そして, neuropil の面積=（核柱の断面 積の和）-（神経細胞体の面積の和）である ${ }^{3}$ 。

\section{観察}

40 胎週齢の前庭神経外側核では, “材料と方法” の項で述べたよらに切片標本を重ねて実体顕微鏡 下に核柱として観察することにより，二つの核柱 として外側亜核と内側严核に分かれていることを 確認した。本核は下小脳脚・三叉神経脊䯣路・前 庭神経上核などに聿まれていること，また顕微鏡 の倍率を高めて, 濃染した Nissl 小体を含む大き い神経細胞体を見つけることにより他の神経核か ら区別した。外側亜核の神経細胞は比較的大ささ のそろった多極性のものが多く, 内側亜核の神経 細胞は紡錘形・卵円形・多極性のものから成って いた。な拈, 内側亜核の神経細胞の一部に pyknosis の所見が観察できた。右内側亜核と外 側垔核を図 1 に示す。

\section{計測結果}

左右それぞれの外側亜核・内側亜核の計測值 (核柱断面積. 核柱体積. 切片当りの神経細胞数 - 核柱の神経細胞数・神経細胞面積・神経細胞周 長・CR・NI）を参考のために表 1 亿示す。なお，

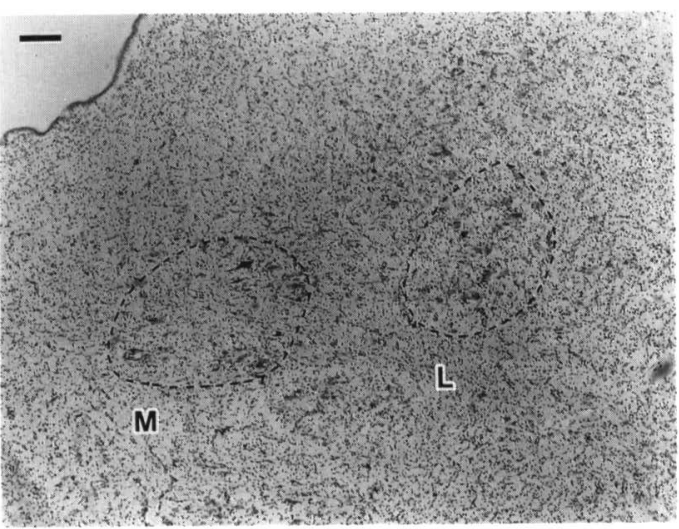

図 140 胎週粭の右前庭神経外側核 (K-B 染色) $\mathrm{M}$ : 内側带核 ; L: 外側亜核 ; スケールバー は $100 \mu \mathrm{m}$ 。

核柱体積 $=$ 断面積の平均值 $\times$ 切片枚数 $\times$ 標本厚, 切片枚数 $=$ 標本最大番号 - 最小番号 +10 で計算し た。

\section{考察}

ヒトの脳の細胞成熟過程の定量的な観察は最近 始まったばかりであるが, すでに, いくつかの脳 神経核や小脳核で定量的な発達を検討した論文が ある4) 12)。しかしまた゚脳の全貌が明らかにされ るには程遠い。ヒト, とりわけ胎児に関寸る研究 は, 材料収集 - 研究手段の制約・胎柃の正確な把 握・病理学的変化の可能性などの点で非常に困難 である。定量的な研究ではデータの信頼性を高め るために十分な例数が必要であるが, 現状では少 ない材料で可能な限り情報量の多い研究手段が望 ましく, 連続切片法はその一つの有力な手法であ る13)。前庭神経核については, 発達の形態計測学 的報告は見つからなかった。平衡機能の発達を調 ベる手がかりとして, ヒト胎児脳の連続切片標本 を用いて形態計測を行い計測結果の項に記したパ ラメータを算出し, 胎週龄順の経時的検討を行う ことにした。

形態計測を行うにあたり，まず標本の収縮率を 最小にすることが大切である。クロム酸による二 次固定を採用したセロイジン切片での標本の収縮 率を計算すると，長さで約 $10 \%$ であり，パラフィ ン包埋や凍結法などの他の方法に比べて最も収縮 率が小さい3)。計測に当たっては対象とする細胞 数, 面積, 周長が一度の測定で全て行えるように 
表 140 胎過領の前庭神経外側核

左

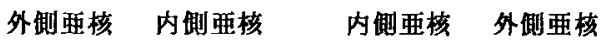

\begin{tabular}{|c|c|c|c|c|}
\hline 核柱断面皘（平均值, $\mathrm{nm}^{2}$ ) & 0.21 & 0.27 & 0.33 & 0.14 \\
\hline 核柱体掅 $\left(\mathrm{mm}^{3}\right)$ & 0.25 & 0.41 & 0.39 & 0.21 \\
\hline 神経緗胞数／切片 & 39.3 & 39.4 & 50.5 & 18.8 \\
\hline 核柱の神経紐胞数 & 1570 & 1970 & 2020 & 940 \\
\hline 細胞面積 $\left(\mu \mathrm{m}^{2}\right)$ & $307 \pm 155$ & $352 \pm 226$ & $260 \pm 189$ & $348 \pm 172$ \\
\hline 周長 $(\mu \mathrm{m})$ & $64.6 \pm 21.4$ & $72.9 \pm 31.5$ & $68.8 \pm 30.3$ & $80.1 \pm 28.1$ \\
\hline $\mathrm{CR}$ & $0.9 \pm 0.1$ & $0.8 \pm 0.2$ & $0.7 \pm 0.2$ & $0.7 \pm 0.2$ \\
\hline N I & 5.0 & 6.5 & 6.2 & 7.2 \\
\hline
\end{tabular}

設計した画像解析装置と，オンラインで入力でき るコンピェータプログラムが最も使いやすい3。 当教室の開発による形態計測システムソフトと LOTUS123を使用すると計測数を数千個をで增 やすことも可能である。

神経細胞体の成熟度を調べ，比較するために， その面積值と周長から真円率 (CR) を求めた。 幼若な細胞は円（真円率1.0）に近く，成熟した ものは突起が発達するので,円から遠く離れる(真 円率0.8，0.6などのよらにことになる3》。

neuropil とは中枢神経系の灰白質塊を作り，内 部に神経細胞体が埋め込まれている軸索や樹状突 起と神経膠の細胞体と突起のフェルト状の複雑な 網で，その中には血管や結合組織も含まれる。脳 の発達とともに neuropil が増加することは他の ニューロンとの線維連絡が増加することを間接的 では亦るが示している。よって神経細胞 1 個が持 つ周囲の neuropil の量（面積）を表す NI を, 脳 の発達を検討する上でとりあげることは重要であ る)。

上記のよう飞形態計湘学的評価法には様々な特 長があり, 今までに行われた脳神経核の発達の形 態計測学的研究結果4)577)899) 11) と前庭神経核の発 達を比較すること夕可能である。

Olszewski \& Baxter ${ }^{14)}$ 你七ト成人の前庭神経 外側核を分類して Subnucleus lateralis (外側亜 核) と Subnucleus medialis (内側垔核) として いる。前者は neuropil が多く, 細胞成分が疎で
あるが，後者は neuropil が少なく，細胞成分が 密である。神経細胞については前者は大型の多極 性や紡錘形などで，Nissl 小体が多くて濃染する。 後者は大部分が中型で紡錘形, 卵円形, 多極性の 中等度の濃さの染色性のものであるが，一部に卵 円形の大型のものがわずかに含まれる。今回，七 ト40胎週齢の前庭神経外側核の観察では, 外側要 核・内側亜核共に数力所に大型の細胞や chromatolysis を疑わせるものや, pyknosis といった 変性細胞が若干存在し, Olszewski \& Baxter の 細胞構築像とは，やや異なった所見であった。

タイトルに示したように, 今報告は形態計測学 的方法論が主体である。そして，参考のため以計 測データを 1 例紹介した。その計測データは，核 柱の神経細胞数 - 細胞面積共に, 左右の内側 - 外 側带核で差が認められるので，その原因は何かと いう指摘が有るかもしれない。しかし，它の原因 を考察する前に, 数少ない貴重な標本でまずデー タを出し，集積してゆくことが必要であると考 え，計測値を示した。よってデータについてのコ メントは控光る。今後, 前庭神経外側核を胎週齢 を追って計測・統計解析を行い，その発達過程を 考察する予定である。

まとめ

1. 連続切片で前庭神経外側核の発達を評価しう ることを示した。

2. 前庭神経外側核を㝷核に分けて検討した。

3. 核柱・神経細胞の大きさを数量的に計測しら 


$$
\text { ることを示した。 }
$$

4. neuropil を数量的に評価する方法を示した。

\section{謝辞}

コンピュータ解析に御協力を頂さました大阪市 立大学生活科学部生活環境学教室岡田 明助教授 に深謝致します。

\section{文献}

1 ) 後藤 昇：前庭系の発達. Equilibrium Res 53: 103-109, 1994

2) Goto N: Discriminative staining methods for the nervous system: LPH triple stain and subsidiary staining methods. Stain Technol 62: 305-315, 1987

3 ）後藤 昇, 山口勝之, 奈良隆寛, 他: 脳の発 達の形態計測学的評価法について. 脳と発達 20: 308-313, 1988

4) Hamano S, Goto N, Nara T: Development of the human motor trigeminal nucleus. Pediatr Neurosci 14: 230-235, 1988

5 ) Nara T, Goto N, Yamaguchi K: Development of the human hypoglossal nucleus: a morphometric study. Dev Neurosci 11: 212-220, 1989

6) Yamaguchi K, Goto $\mathrm{N}$, Yamamoto $\mathrm{T}$ : Development of human cerebellar nuclei. Acta Anat 136: 61-68, 1989

7 ) 奈良隆寛, 後藤 昇, 野崎秀次, 他：ヒト胎 児顔面神経核の発達. 脳と発達 21: 453-459, 1989

8 ) Hamano S, Goto N, Nara T, et al: Develop- ment of the human mesencephalic trigeminal nucleus: a morphometric study. Dev Med Child Neurol 32: 621-628, 1990

9 ) Nara T, Goto N, Hamano S: Development of the human dorsal nucleus of vagus nerve: a morphometric study. J Auton Nerv Syst 33: 267-276, 1991

10) Nozaki $H$, Goto $N$, Nara T: Development of the human pontine nuclei: a morphometric study. Dev Brain Res 65: 13-20, 1992

11) Nara $T$, Goto $N$, Nakae $Y$, et al: Morphometric development of the human auditory system: ventral cochlear nucleus. Early Hum Dev 32: 93-102, 1993

12) Milutinović B, Gudović R, Malešević J: Regressional changes of human cerebellar cortex and hypoglossal nucleus during development. J Hirnforsh 33: 357-360, 1992

13）山口勝之, 後藤 昇, 奈良隆寛 : 七上胎生期 小脳の発達 : 構造別体積の検討. 脳と発達 20: 3-9, 1988

14) Olszewski J, Baxter D: Nucleus vestibularis lateralis. In Cytoarchitecture of the human brain stem. pp 76-77, S. Karger, Basel, 2nd ed, 1982

$$
\left(\begin{array}{l}
\text { 原稿到着 : 平成 } 7 \text { 年 } 3 \text { 月 } 7 \text { 日 } \\
\text { 別刷請求先 : 藤井まゆみ } \\
\text { 个4 } 414 \text { 静岡県伊東市猪戸1-1-3 } \\
\text { 藤井耳鼻咽喉科医院 }
\end{array}\right)
$$

